\title{
Glaciers Fluctuation over the Last Half Century in the Headwaters of the Enguri River, Caucasus Mountains, Georgia
}

\author{
Levan G. Tielidze, George Lominadze, Nino Lomidze \\ Vakhushti Bagrationi Institute of Geography, Ivane Javakhishvili Tbilisi State University, Tbilisi, Geogia \\ Email: levan.tielidze@tsu.ge, levani.tielidze@gmail.com
}

Received 25 February 2015; accepted 7 April 2015; published 10 April 2015

Copyright (C) 2015 by authors and Scientific Research Publishing Inc.

This work is licensed under the Creative Commons Attribution International License (CC BY). http://creativecommons.org/licenses/by/4.0/ (c) (i) Open Access

\begin{abstract}
The article considers the variability glaciers parameters of Headwaters of the Enguri River in the years of 1960-1986-2014. The headwaters of The Enguri River are located on the southern slope of the Greater Caucasus, in Georgia. Detailed morphologic and morphometric description of glaciers is given. During our research, we used the topographic maps of 1960 and Landsat L5 TM (Thematic Mapper) aerial images, taken in August 1986 and 2014, and the GPS data of 2014. In the mentioned study, except for the old topographic maps and aerial images we used the climate information that we have collected from Mestia weather station (Mestia is the regional center of Zemo Svaneti), which is the only operating weather station in region. Along with the dynamics of glaciers the course of the air temperature has been identified, mainly trends of mean annual and monthly air temperatures for different periods 1961-2013, 1961-1986, 1987-2013 are made. According to them, main reasons for glacier retreat are analyzed.
\end{abstract}

\section{Keywords}

Glaciers Dynamic, Glaciers of Georgia, Caucasus Mountains, Remote Sensing, Adishi, Khalde and Shkhara Glaciers

\section{Introduction}

Glaciers and the area occupied by them are the integral part of environment. They always play an important role in the evolution of natural conditions and, proceeding from this, in the evolution of the biosphere [1]. It is widely recognized that glaciers are highly sensitive to climatic change, and much research has focused on their recent (1950s onward) response to increased global temperatures in an attempt to evaluate future changes under given

How to cite this paper: Tielidze, L.G., Lominadze, G. and Lomidze, N. (2015) Glaciers Fluctuation over the Last Half Century in the Headwaters of the Enguri River, Caucasus Mountains, Georgia. International Journal of Geosciences, 6, 393-401. http://dx.doi.org/10.4236/ijg.2015.64031 
climate scenarios [2]. Recent atmospheric warming has caused increased mass loss of glaciers all over the world [3] [4], which significantly contributes to present sea-level rise [5] [6] and affects the runoff regimes of glacierized catchments in different regions around the globe [7]-[9].

Mountain glaciers are highly sensitive to variations in temperature and precipitation [10] and thus represent a good indicator of climate changes over recent centuries [11] [12]. Since the end of the Little Ice Age (LIA), mountain glaciers have retreated significantly, a trend that has accelerated over the last few decades and is expected to persist in the coming century [13] [14].

In order to make an accurate assessment of the contribution of glaciers to the global water balance, it is necessary to monitor changes in the areal extent of glaciers, as well as other parameters such as their volume and mass balance [15]. Additionally, very small glaciers are often under-represented in glacier inventories. Although these glaciers only represent a small fraction of the cryosphere, they are very important water resources to local communities, and play a significant role in the water budget of many regions of the world, where their summer melt strongly determines the seasonal runoff regime. Regular monitoring of their behavior assumes added importance given that smaller glaciers are known to respond more rapidly to climate change [16]. Glacial melt waters are one of the main factors in river runoff formation in the mountainous areas of Georgia. Their erosive action is determined by the ablation intensity during the day [17].

\section{Study Area}

The Caucasus is one of the major mountain systems in Eurasia [17] [18], stretching 1300 km from the Black Sea in the west to the Caspian Sea in the east [19]. The Caucasus mountain range is streatched along the territory of Georgia at about $750 \mathrm{~km}$, the glaciers are concentrated in the southern and partly in the northern slopes of the watershed range, as well as in the side range and branch-ranges of the Greater Caucasus [1]. According to the morphological and morphometric characteristics the Greater Caucasus can be divided into three parts within Georgia-Western, Central and Eastern [1] [20].

Central Caucasus sector is the highest hypsometrically; it is characterized by a complex geological structure and is very interesting by glacial-geomorphological point of view. Its western boundary coincides with the Dalari pass and runs along the Enguri-Kodori Rivers' watershed (Kharikhra range), while its east boundary coincides with the Jvari Pass and then runs along the bottom of the river gorges of Tergi-Bidara-Mtiuleti's Aragvi [21]. Orographic structure of the southern slopes of the Central Caucasus is different from the similar slopes of the Eastern and Western Caucasus. It is characterized by a large extent and great depth of fragmentation. Erosion and tectonic processes are important in the formation of contemporary relief, while the glacial processes -in the high mountain zone.

The headwaters of the Enguri River embraces the Central Caucasus (Figure 1) from the Mount Gisstola to the Mount Namkvani, or the headwaters of the Enguri River itself and the river basins of its righthand tributariesAdishura and Khaldechala. In the literature this section of the Greater Caucasus is known as a Bezingi Wall. The southern slope profile the Bezingi Wall is short and steep, which fully reflects the name of the "Wall" (wooden). There are peaks with the height of over 5000 meters.

There are large valley glaciers in the territory within the mentioned frames, such as: Adishi, Khalde, Shkhara and Namkvani. The river gorges have well expressed trough forms along their entire length.

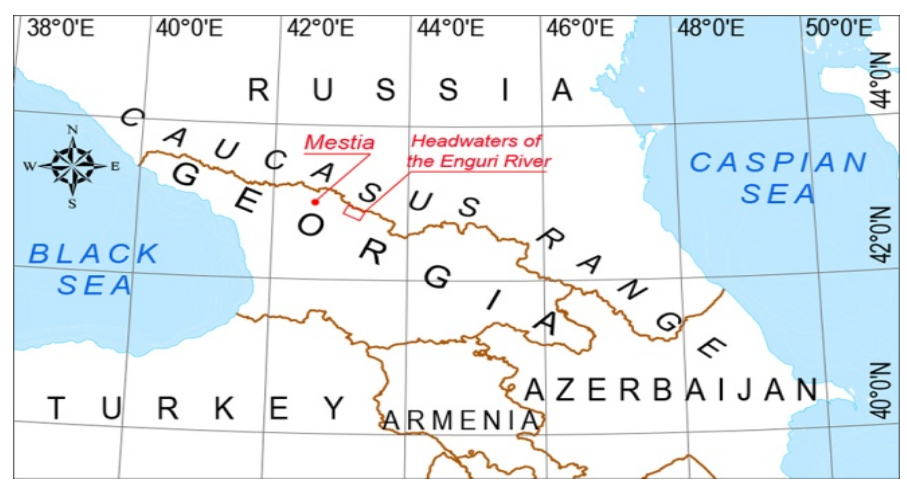

Figure 1. Location of the Enguri River headwater. 
Morphologically the largest area is occupied by the compound-valley glaciers, while by the number dominate the hanging glaciers. According to the area the valley glaciers are in the second place (Figure 2). As for the exposition of the glaciers the first place by the number and area belong to the glaciers of the overall southern exposition. There is only one glacier with the western exposition.

\section{Data and Methods}

Many of the world's glaciers are in remote areas, meaning that land-based methods of measuring ice volume and velocity changes are expensive and labour-intensive. Remote-sensing technologies have offered a solution to this problem [22]-[27], through the use of Landsat satellite imagery.

We seek to reconstruct the extent of Glaciers in Headwaters of The Enguri River using archival and modern datasets. Baseline data come from 1:50,000 topographic maps drawn up in the 1960s by the Department of Geodesy and Cartography of the former Soviet Union. These maps are in the Pulkovo-1942 projection. We used standard transformation parameters to re-project the maps in Universal Transverse Mercator (UTM), zone 38North on the WGS84 ellipsoid, to facilitate comparison with modern datasets.

The modern sequence of glacier terminus positions is established using cloud-free Landsat Thematic Mapper (TM) images collected on August 6, 1986 (Landsat 5) and August 8, 2014 (Landsat 5). Rugged terrain in the study area means that each image must be orthorectified, which we accomplish using the digital elevation dataset. TM images have a pixel resolution of $28.5 \mathrm{~m}$ for the visible bands used in this study. Generating a time series requires all images to be accurately co-registered to one another. To facilitate mapping the glacier boundaries, we produced a color-composite scene for each acquisition date, using bands 7 (short-wave infrared), 4 (near infrared) and 2 (blue). Each glacier boundary was manually digitized by a single operator. Manual digitizing by an experienced analyst is usually more accurate than automated methods for glaciers with heavy debris cover [28], such as Glaciers in Headwaters of the Enguri River. Combining the images with the baseline topographic map allows us to estimate the variability of Glaciers in 1960-1986-2014 years.

It is important the existence of climate elements especially air temperature data to study the dynamics of glaciers. We managed to obtain the average daily air temperature data of Mestia weather station since 1960 till 2013 from the National Agency of Environment.

The temperature anomalies for the last 53 years were restored by the above mentioned climatological information. The mean monthly and multi-year mean temperatures were calculated as for whole period as well as 1961-1986 and 1987-2013.

During a brief follow-up field visit on August 2014, we surveyed the terminus using global positioning system (GPS) methods.

\section{Results and Discussions}

Large changes in mountain glacier dynamics are usually only apparent over periods of decades [29]-[33]. Because our aim was to determine changes of quantity and areas of glaciers not for any short period, but for last half century.

By the data of 1960 there were 21 glaciers in the basin with the total area of $34.4 \mathrm{~km}^{2}$ (Figure 3(a)). By the data of 1986 there were 24 glaciers in the basin with the total area of $29.9 \mathrm{~km}^{2}$ (Figure 3(b)). According to the last years field studies and the data of space images of 2014 we have 23 glaciers there with the total area of 27.1 $\mathrm{km}^{2}$ (Figure 3(c)). This is $12.13 \%$ of the total area of the glaciers of the Enguri River Basin.

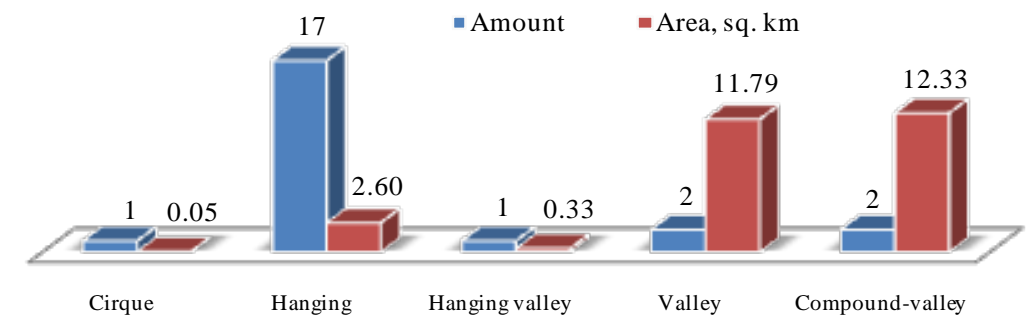

Figure 2. Distribution of the glaciers in the Enguri River headwaters according to the morphological types. 


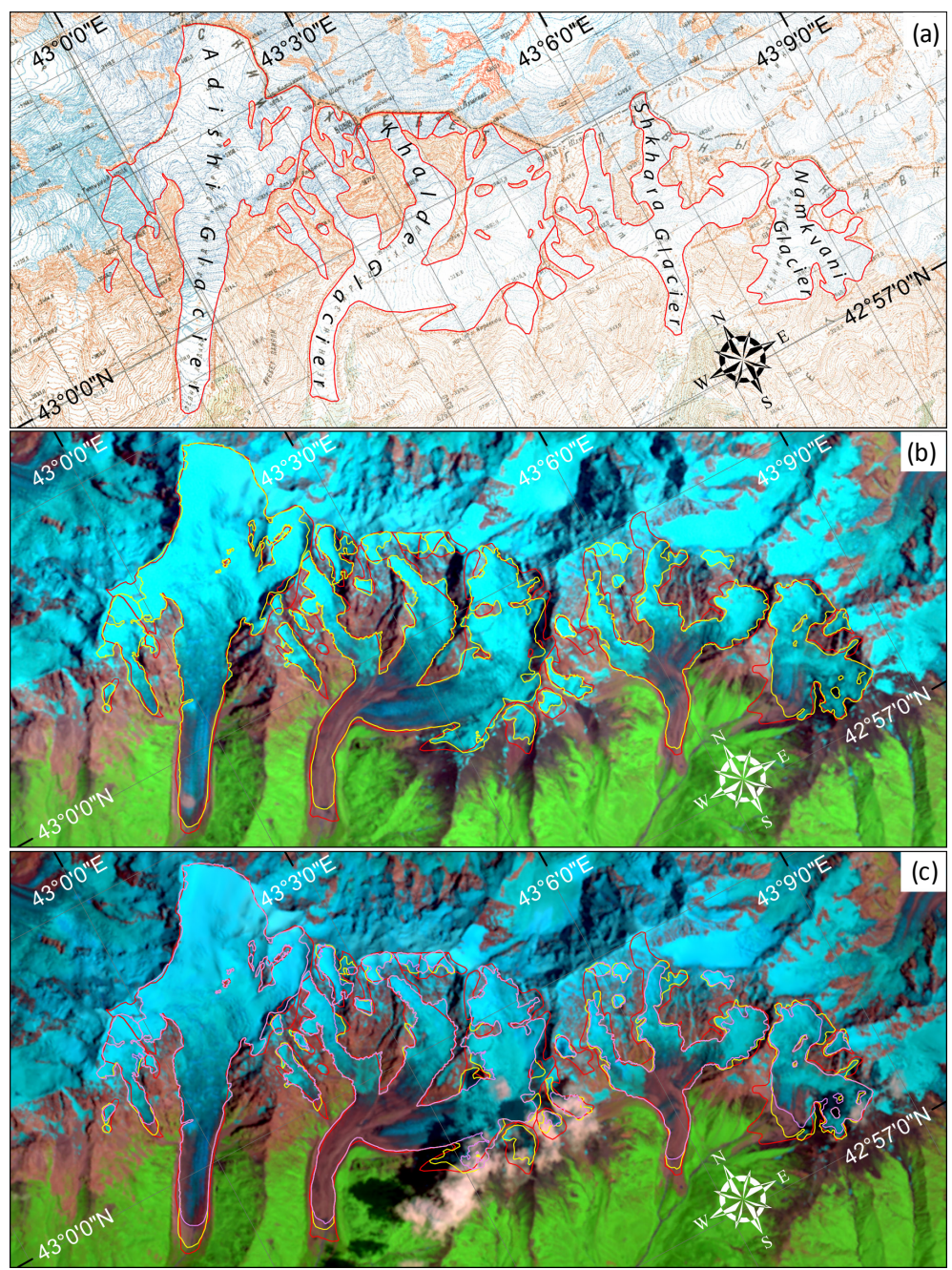

Figure 3. Glaciers of the Enguri River headwaters in 1960 (a); 1986 (b); 2014 (c).

89.0\% of the entire basin area is a share of 4 main glaciers-Adishi $9.5 \mathrm{~km}^{2}$, Khalde $8.8 \mathrm{~km}^{2}$, Shkhara 3.6 $\mathrm{km}^{2}$ and Namkvani $2.3 \mathrm{~km}^{2}$. The sizes of the rest of the glaciers do not exceed $1.0 \mathrm{~km}^{2}$.

Adishi glacier is one of the beautiful glacier in the Greater Caucasus, it is divided into three parts: with the firn valley above 3800 meters, which is surrounded by the high peaks (Tetnuldi, Adishi, Gistola, Lakutsa, etc.), also with the grandiose icefall ( 1000 - 1300 meters in height) and the classic ice tongue. The Adishi glacier is a valley glacier with the south-western exposition.

The second section of the glacier - the icefall is of grandiose sizes; the glacier tongue flows down to the height of $\sim 1500$ meter by the angle of $\sim 50^{\circ}$ and make visitors admired. The icefall is 700 - 800 meters in width. It is characterized by disordered cracks. There are many seracs and clifs there. The icefall is halted at a side of Tetnuldi at a height of 40 - 50 meters. In this section the glacier experiences an intense mechanical destruction. Demolished ice accumulates at the base of the icefall and creates a cone of it, which joins the glacier tongue later.

The shape of the glacier changes dramatically from the ice base $(2650 \mathrm{~m})$; the tongue slightly inclined $\left(\sim 10^{\circ}\right.$ $15^{\circ}$ ) and in a shape of a beautiful fan ends at the height of 2485 meters above sea level. The ice tongue length is $\sim 2.5$ kilometers. According to the description of 1960 the glacier tongue was covered with a small amount of weathered material, but the last visual inspection and observation of space image shows that the amount of weathered material has sharply increased, especially in the sides and in the last part. The tongue is raised in the central part. The ogives stretch along the entire length of it and give a peculiar air to its beauty. The surface of 
glaciers is wavy, with numerous glacial wells, mills and ablation forms. There are many groove and gorges in its surface created by melted water. Glacier surface devoid of cracks, they are only found in its sides and at the bottom of the icefall.

The well expressed stade moraines stretch along the both sides of the glacier ice, which make curve after $~ 1.5$ $\mathrm{km}$ from the end of the tongue and transform into the terminal stage moraine. Micro stade moraines are developed on the slope of the stade moraine in front of the glacier and at the bottom of the gorge. Directly in front the ice tongue there can be found several annual curve hillocks.

The area of Adishi glacier was $10.5 \mathrm{~km}^{2}$ and tongue was terminated on $2330 \mathrm{~m}$. a.s.l., in 1960; The area was $9.7 \mathrm{~km}^{2}$ and tongue was terminated on $2400 \mathrm{~m}$. a.s.l. In 1986, while it was $9.5 \mathrm{~km}^{2}$ and tongue was terminated on $2485 \mathrm{~m}$. a.s.l., in 2014. The glacier length has shortened by $\sim 0.5 \mathrm{~km}$ between 1960-2014 (Figure 4, Table 1).

Khalde glacier is a compound-valley glacier with the south-western exposition. The firn valley is surrounded by the highest peaks of the Greater Caucasus mountain range (Shkhara, Pushkin peak, Janga, Rustaveli peak, etc.), the heights of which exceed $5000 \mathrm{~m}$. In the upper part it is represented by the three icefalls, which are characterized by a large fracturing. The icefalls are combined at a height of 2800 meters. And below, the ice tongue changes its direction to the south-west and ends at a height of 2545 meters. At the place of junction the glacier expands and creates the vast stadium, below of which the glacier flows as one powerful flow.

The variability of morphological parameters of Khalde glacier in 1960-1986-2014 is shown in Table 1.

The end part of the glacier tongue is covered with a thick moraine cover which protects the glacier surface from the intensive melting. That is why in the years of 1960-2014 the average annual retreat of the Khalde glacier is fixed $\sim 5.5 \mathrm{~m} /$ year. This is the lowest figure in this size of glaciers of the Greater Caucasus. There are two medial moraines in the middle of the glacier tongue. Stade moraines stretch along the both sides of the Khalde glacier, which make curves and transform into the terminal moraine.

Shkhara Glacier is a compound-valley glacier with the southern exposition. It consists of three flows that are
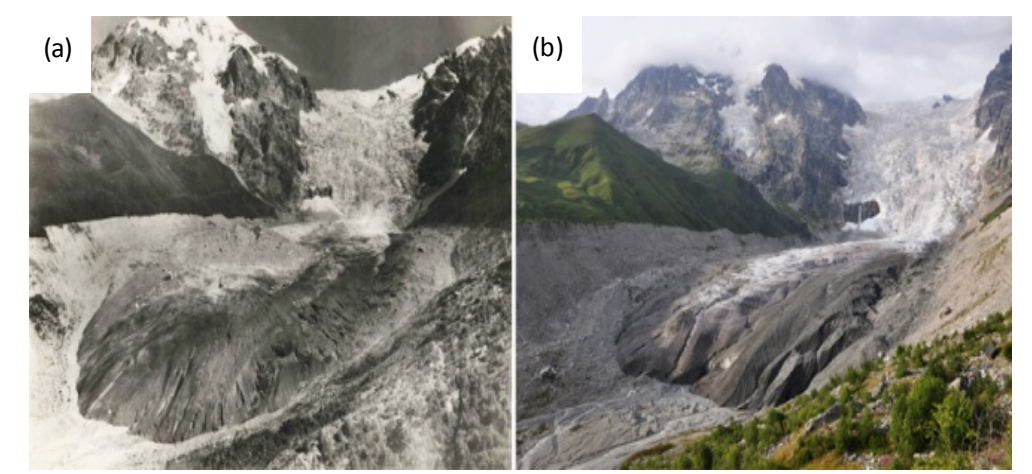

Figure 4. Adishi Glaciers tongue in 1960 (a); 2014 (b).

Table 1. Variability of morphological parameters of Adishi, Khalde and Shkhara glaciers in 1960-1986-2014.

\begin{tabular}{|c|c|c|c|c|}
\hline Glacier name & Years & Area $\mathrm{km}^{2}$ & Height of the tongue m. a.s.l. & Length km \\
\hline \multirow{3}{*}{ Adishi } & 1960 & 10.5 & 2330 & 7.4 \\
\hline & 1986 & 9.7 & 2400 & 7.2 \\
\hline & 2014 & 9.5 & 2485 & 6.9 \\
\hline \multirow{3}{*}{ Khalde } & 1960 & 10.9 & 2480 & 7.8 \\
\hline & 1986 & 9.5 & 2520 & 7.6 \\
\hline & 2014 & 8.8 & 2545 & 7.5 \\
\hline \multirow{3}{*}{ Shkhara } & 1960 & 5.0 & 2490 & 4.0 \\
\hline & 1986 & 4.0 & 2500 & 3.9 \\
\hline & 2014 & 3.6 & 2545 & 3.7 \\
\hline
\end{tabular}


combined at a height of 2900 meters above sea level. From there the ice tongue is of south-western direction. The glacier tongue is quite cracked, especially its right section. From the middle part of the glacier's surface is covered by loose material. Its surface is rich in ablation forms.

The area of Shkhara glacier was $4.0 \mathrm{~km}^{2}$ and tongue was terminated on $2490 \mathrm{~m}$. a.s.l., in 1960; The area was $3.9 \mathrm{~km}^{2}$ and tongue was terminated on $2500 \mathrm{~m}$. a.s.l. in 1986, while it was $3.7 \mathrm{~km}^{2}$ and tongue was terminated on 2545 m. a.s.l., in 2014. In 1960-2014 the glacier length shortened approximately by $\sim 0.3 \mathrm{~km}$ (Table 1 ).

As the glacier surface is covered with a thick weathered material, the ice melt very weak. In the years of 1960-2014 the retreating indicator is 5.5 meters per year. Unlike the ice tongue it seems that the melting is quite intensive in the feeding area, because all of the three flows are weakened compared with the year of 1960.

There are well expressed lateral stade moraines to the both sides of the glacier, which are ended by the terminal moraine.

For the investigation of Dynamics of glaciers is important to analyze the climatological information, mainly air temperature data and precipitation for the same period. In investigated area the meteorological observation was started in 1930 and nowadays Mestia meteorological station is the only station and is located at $1440 \mathrm{~m}$. a.s.l. (Figure 1).

Mestia multi-year mean air temperature was calculated for the last 53 years, which made $+6.0^{\circ} \mathrm{C}$. The diagram of mean monthly temperature anomalies for 1961-2013 was made (Figure 5) by those temperature data.

From the diagram is shown that long-term trend is a positive. The warm anomaly periods were: 1966-1968, 1994-1997, 1998-2002 and 2008-2012. The negative anomaly periods were: 1964-1965, 1983-1986, 1988-1994 and 2003-2008.

As our research period comprises approximately last 50 years we it divide into two periods 1961-1986 and 1987-2013. As we have mentioned above Mestia multi-year mean air temperature made $+6.0^{\circ} \mathrm{C}$. In the same period the temperature trend is a positive (Figure 6). The analysis of only 1961-1986 period shows that the air temperature is lower by $0.2^{\circ} \mathrm{C}$ than multi-year mean and makes $+5.8^{\circ} \mathrm{C}$. Also the temperature trend is a negative (Figure 6). The multi-year mean of $1987-2013$ period is the highest and makes $+6.1^{\circ} \mathrm{C}$. The temperature trend is a sharply positive (Figure 6).

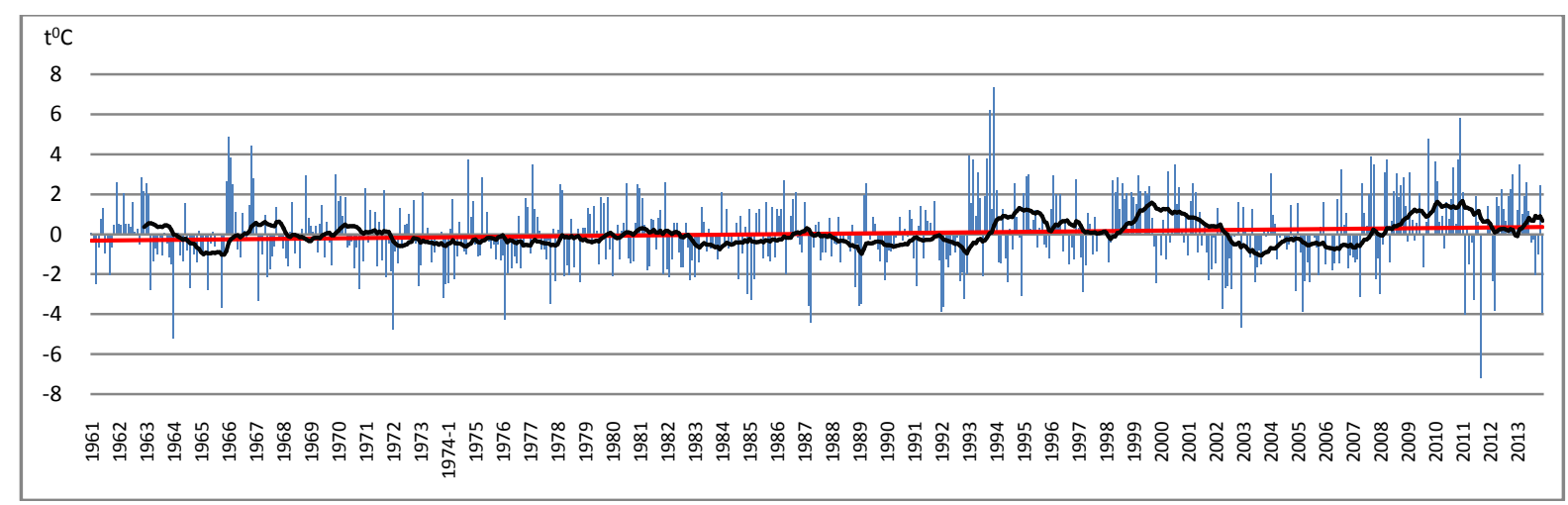

Figure 5. The Mestia temperature anomalies during the 1961-2013.

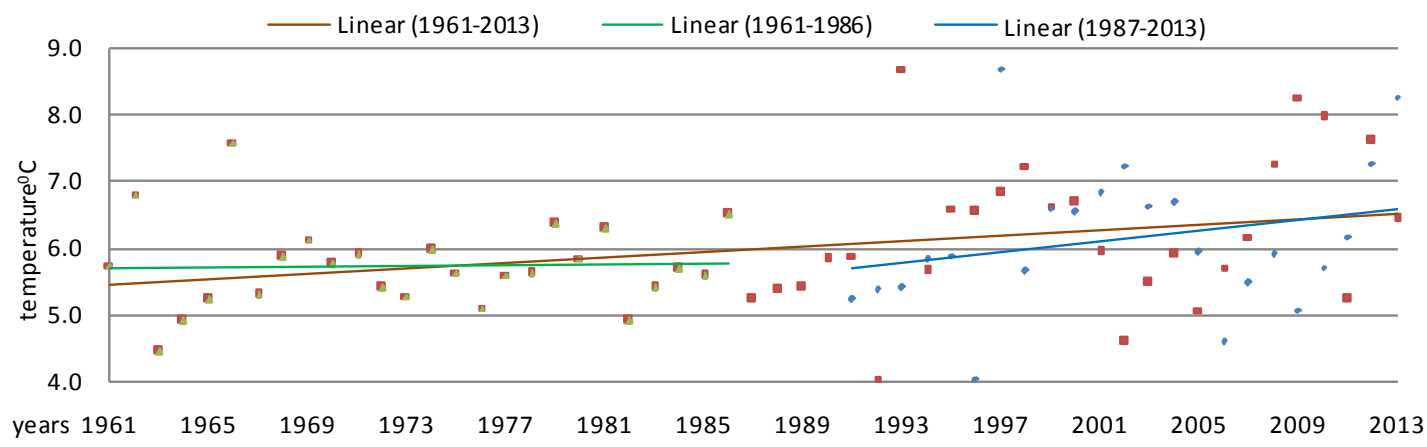

Figure 6. Trends of mean anual air temperatures for 1961-2013, 1961-1986, 1987-2013. 


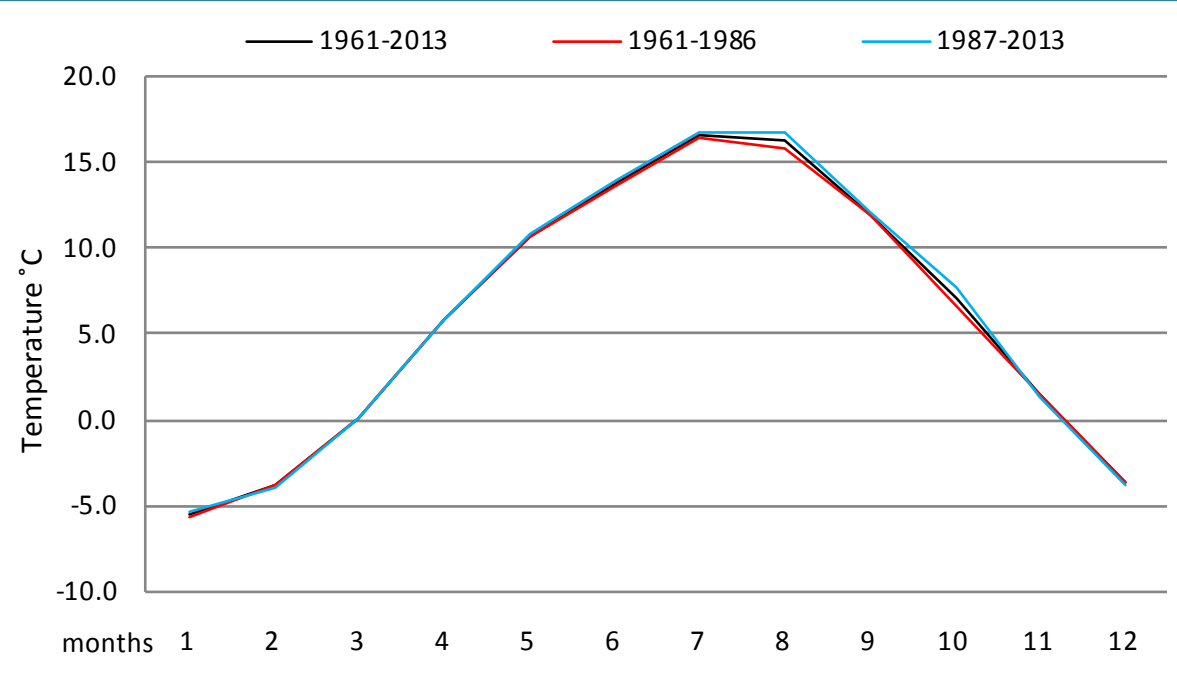

Figure 7. Mean monthly air temperatures for 1961-2013, 1961-1986, 1987-2013.

According to the data of Mestia meteorological station the warmest month is July in the region. July mean temperature is $+16.6^{\circ} \mathrm{C}$, August is $+16.3^{\circ} \mathrm{C}$, and June is $+13.8^{\circ} \mathrm{C}$. The glacier melt in the Caucasus is particularly strong in June, July and August (JJA) and variations in JJA temperatures are of particular importance [34].

The mean monthly temperatures were also divided into two periods (like a multi-year mean) 1961-1986 and 1987-2013. This revealed that July mean temperature for $1961-1986$ was lower by $0.2^{\circ} \mathrm{C}$, and July mean temperature for $1987-2013$ was higher by $0.3^{\circ} \mathrm{C}$ compare with July mean temperatures for 1961-2013 (Figure 7).

From the figure is also apparent that the period from June to November and January itself for 1987-2013 compare with the same period for 1961-2013 is characterized by high temperatures. This condition is directly connected with the intensity of glacier melt.

\section{Conclusions}

Changes in the dynamic parameters even of relatively small glaciers may have a disproportionately large impact on climate [35]. So, the relatively small scale research outcomes may be of particular importance for studying the regional climate change.

The investigation revealed that the area of glaciers has retreated by $21.3 \%$, and their quantity has enhanced by 9.5\% in the source of Enguri River headwaters. Several small size glaciers were developed due to the melt in the firn area of the Khalde glacier, while reduction of glacier quantities together with shrinking of their areas was observed almost in all glacial basin of the Southern slope of the Caucasus during the same period.

In the mentioned period was not observed so large retreat of glaciers. The less rate of retreat is fixed on Shkhara and Khalde glaciers and makes $\sim 5.5 \mathrm{~m}$ /year, the largest retreat on Adishi glacier compiles $\sim 9.3 \mathrm{~m}$ /year, accordingly the tongue of Adishi glacier was lifted higher compared with other glaciers, particularly from 2330 $\mathrm{m}$ up to $2485 \mathrm{~m}$.

The trends of mean annual air temperatures and their anomalies are positive for 1960-2013. The mean annual air temperature for $1987-2013$ is higher $\left(+0.1^{\circ} \mathrm{C}\right)$ compared with long-term mean. Also the period from June to November and January itself for the last 27 years is characterized by high temperatures.

The results of our investigations coincide with the general picture running in southern slope of the Caucasus in last half century. Particularly in the same period together with increasing of air temperature almost in all glaciated basin reduction of glacier quantity and area is observed.

\section{Acknowledgements}

We are grateful to the Shota Rustaveli Georgian National Science Foundation for the financing our research. We would like to express our heartfelt thanks to the Hydro Meteorological Department of the National Agency of the Environment for providing the meteorological data. 


\section{References}

[1] Tielidze, L.G. (2014) Glaciers of Georgia, Monograph. Publ. Color, 254 p. (In Georgian).

[2] Intergovernmental Panel on Climate Change (IPCC) (2001) Climate Change 2001: The Scientific Basis. Cambridge Univ. Press, New York, 881 p.

[3] Zemp, M., Hoelzle, M. and Haeberli, W. (2009) Six Decades of Glacier Mass-Balance Observations: A Review of the Worldwide Monitoring Network. Annals of Glaciology, 50, 101-111. http://dx.doi.org/10.3189/172756409787769591

[4] Radic, V. and Hock, R. (2014) Glaciers in the Earth's Hydrological Cycle: Assessments of Glacier Mass and Runoff Changes on Global and Regional Scales. Surveys in Geophysics, 35, 813-837.

[5] Marzeion, B., Jarosch, A.H. and Hofer, M. (2012) Past and Future Sealevel Change from the Surface Mass Balance of Glaciers. The Cryosphere, 6, 1295-1322. http://dx.doi.org/10.5194/tc-6-1295-2012

[6] Gardner, A.S., Moholdt, G., Cogley, J.G., Wouters, B., Arendt, A.A., Wahr, J., Berthier, E., Hock, R., Pfeffer, W.T., Kaser, G., Ligtenberg, S.R.M., Bolch, T., Sharp, M.J., Hagen, J.O., van den Broecke, M.R. and Paul, F. (2013) A Reconciled Estimate of Glacier Contributions to Sea Level Rise: 2003 to 2009. Science, 340, 852-857. http://dx.doi.org/10.1126/science.1234532

[7] Kaser, G., Grosshauser, M. and Marzeion, B. (2010) Contribution Potential of Glaciers to Water Availability in Different Climate Regimes. Proceedings of the National Academy of Sciences, 107, 20223-20227. http://dx.doi.org/10.1073/pnas.1008162107

[8] Huss, M. (2011) Present and Future Contribution of Glaciers to Runoff from Macroscale Drainage Basins in Europe. Water Resources Research, 47, Article ID: W07511. http://dx.doi.org/10.1029/2010WR010299

[9] Sorg, A., Bolch, T., Stoffel, M., Solomina, O. and Beniston, M. (2012) Climate Change Impacts on Glaciers and Runoff in Tien Shan (Central Asia). Nature Climate Change, 2, 725-731. http://dx.doi.org/10.1038/nclimate1592

[10] Oerlemans, J. (2005) Extracting a Climate Signal from 169 Glacier Records. Science, 308, 675-677. http://dx.doi.org/10.1126/science.1107046

[11] Oerlemans, J. and Fortuin, J.P.F. (1992) Sensitivity of Glaciers and Small Ice Caps to Greenhouse Warming. Science, 258, 115-117. http://dx.doi.org/10.1126/science.258.5079.115

[12] Haeberli, W., Maisch, M. and Paul, F. (2002) Mountain Glaciers in Global Climate-Related Observation Networks. WMO Bulletin, 51, 18-25.

[13] Zemp, M., Haeberli, W., Hoelzle, M. and Paul, F. (2006) Alpine Glaciers to Disappear within Decades? Geophysical Research Letters, 33, L13504. http://dx.doi.org/10.1029/2006GL026319

[14] Braithwaite, R.J., Raper, S.C.B. and Candela, R. (2013) Recent Changes (1991-2010) in Glacier Mass Balance and Air Temperature in the European Alps. Annals of Glaciology, 54, 139-146. http://dx.doi.org/10.3189/2013AoG63A285

[15] Dyurgerov, M. (2003) Mountain and Subpolar Glaciers Show an Increase in Sensitivity to Climatic Warming and Intensification of the Water Cycle. Journal of Hydrology, 282, 164-176. http://dx.doi.org/10.1016/S0022-1694(03)00254-3

[16] Kaser, G., Juen, I., Georges, C., Gomez, J. and Tamayo, W. (2003) The Impact of Glaciers on the Runoff and the Reconstruction of Mass Balance History from Hydrological Data in the Tropical Cordillera Blanca, Peru. Journal of Hydrology, 282, 130-144. http://dx.doi.org/10.1016/S0022-1694(03)00259-2

[17] Tielidze, L.G., Gadrani, L. and Kumladze, R. (2015) A One Century Record of Changes at Nenskra and Nakra River Basins Glaciers, Causasus Mountains, Georgia. Natural Science, 7, 151-157. http://dx.doi.org/10.4236/ns.2015.73017

[18] Gobejishvili, R.G., Tielidze, L.G., Lomidze, N. and Javakhishvili, A. (2012) Monitoring of Glaciers on the Background of Climate Change. Monography, Publ., Universali, 176 p. (In Georgian)

[19] Kotlyakov, V.M., Dyakova, A.M., Koryakin, V.S., Kravtsova, V.I., Osipova, G.B., Varnakova, G.M., Vinogradov, V.N., Vinogradov, O.N. and Zverkova, N.M. (2010) Glaciers of the Former Soviet Union. In: Williams Jr., R.S. and Ferrigno, J.G., Eds., Satellite Image Atlas of Glaciers of the World-Glaciers of Asia, U.S. Geological Survey Professional Paper 1386-F-4, F-5.

[20] Tielidze, L.G., Lomidze, N. and Asanidze, L. (2015) Glaciers Retreat and Climate Change Effect during the Last One Century in the Mestiachala River Basin, Caucasus Mountains, Georgia. Earth Sciences, 4, 72-79.

[21] Maruashvili, L. (1971) Physical Geography of Georgia. Monograph, Publ. Metsniereba. (In Georgian)

[22] Kaab, A. (2002) Monitoring High-Mountain Terrain Deformation from Repeated Air- and Spaceborne Optical Data: Examples Using Digital Aerial Imagery and ASTER Data. ISPRS Journal of Photogrammetry and Remote Sensing, 57, 39-52. http://dx.doi.org/10.1016/S0924-2716(02)00114-4

[23] Kaab, A. (2005) Combination of SRTM3 and Repeat ASTER Data for Deriving Alpine Glacier Flow Velocities in the Bhutan Himalaya. Remote Sensing of Environment, 94, 463-474. http://dx.doi.org/10.1016/j.rse.2004.11.003 
[24] Berthier, E., Vadon, H., Baratoux, D., Arnaud, Y., Vincent, C., Feigl, K.L., Rémy, F. and Legrésy, B. (2005) Surface Motion of Mountain Glaciers Derived from Satellite Optical Imagery. Remote Sensing of Environment, 95, 14-28. http://dx.doi.org/10.1016/j.rse.2004.11.005

[25] Rignot, E. and Kanagaratnam, P. (2006) Changes in the Velocity Structure of the Greenland Ice Sheet. Science, 311, 986-990. http://dx.doi.org/10.1126/science.1121381

[26] Luckman, A., Quincey, D.J. and Bevan, S. (2007) The Potential of Satellite Radar Interferometry and Feature Tracking for Monitoring Flow Rates of Himalayan Glaciers. Remote Sensing of Environment, 111, 172-181. http://dx.doi.org/10.1016/j.rse.2007.05.019

[27] Quincey, D.J. and Glasser, N.F. (2009) Morphological and Ice-Dynamical Changes on the Tasman Glacier, New Zealand, 1990-2007. Global and Planetary Change, 68, 185-197. http://dx.doi.org/10.1016/j.gloplacha.2009.05.003

[28] Raup, B., Kaab, A., Kargel, J., Bishop, M.P., Hamilton, G.S., Lee, E., Rau, F., Paul, F., Soltesz, D., Singh Kalsa, S.J., Beedle, M. and Helm, C. (2007) Remote Sensing and GIS Technology in the Global Land Ice Measurements from Space (GLIMS) Project. Computers \& Geosciences, 33, 104-125. http://dx.doi.org/10.1016/j.cageo.2006.05.015

[29] Lliboutry, L. and Reynaud, L. (1981) “Global Dynamics” of a Temperate Valley Glacier, Mer de Glace, and Past Velocities Deduced from Forbes’ Bands. Journal of Glaciology, 27, 207-226.

[30] Span, N., Kuhn, M. and Schneider, H. (1997) 100 Years of Ice Dynamics of Hintereisferner, Central Alps, Austria, 1894-1994. Annals of Glaciology, 24, 297-302.

[31] Vincent, C., Vallon, M., Reynaud, L. and Meur, E.L. (2000) Dynamic Behaviour Analysis of Glacier de Saint Sorlin, France, from 40 Years of Observations, 1957-97. Journal of Glaciology, 46, 499-506. http://dx.doi.org/10.3189/172756500781833052

[32] Vincent, C., Soruco, A., Six, D. and Le Meur, E. (2009) Glacier Thickening and Decay Analysis from 50 Years of Glaciological Observations Performed on Glacier d'Argentiere, Mont Blanc Area, France. Annals of Glaciology, 50, 73-79. http://dx.doi.org/10.3189/172756409787769500

[33] Span, N. and Kuhn, M. (2003) Simulating Annual Glacier Flow with a Linear Reservoir Model. Journal of Geophysical Research, 108, 4313. http://dx.doi.org/10.1029/2002JD002828

[34] Shahgedanova, M., Hagg, W., Zacios, M., Hassell, D. and Popovnin, V. (2009) An Assessment of the Recent Past and Future Climate Change, Glacier Retreat, and Runoff in the Caucasus Region Using Dynamical and Statistical Downscaling and HBV-ETH Hydrological Model. Springer, Netherlands.

[35] Meier, M.F., Dyurgerov, M.B., Rick, U.K., O’Neel, S., Pfeffer, W.T., Anderson, R.S., Anderson, S.P. and Glazovsky, A.F. (2007) Glaciers Dominate Eustatic Sea-Level Rise in the 21st Century. Science, 317, 1064-1067. http://dx.doi.org/10.1126/science.1143906 